\title{
THE CHLORIDE EXCRETION TEST (CUTLER-WILDER-POWER TEST) IN ASTHENIA
}

\author{
BY KARL E. PASCHKIS 1 AND ALISON H. PRICE \\ (From the Endocrine Clinic, Department of Medicine, Jefferson Medical College \\ and Hospital, Philadelphia)
}

(Received for publication March 22, 1943)

The clinical picture of Addison's disease is well recognized and understood. It is very likely, from analogy with other diseases or deficiencies, that milder cases occur which, for the most part, are not recognized as such. However, the diagnosis of "mild hypoadrenia" made by a number of authors (1 to 5) rests on clinical impression and on the therapeutic effect of substitution therapy alone. These criteria for diagnosis are insufficient and the procedure of treatment is costly. It was therefore decided to investigate the adrenal cortical function in asthenic patients.

\section{MATERIAL AND METHODS}

Fifty patients have been studied. Of these, 27 complained of varying degrees of asthenia. Carbohydrate metabolism was studied by means of the glucose tolerance test, 100 grams of glucose being given orally. Blood sugar determinations were done by Benedict's method. The values reported are therefore "true sugar values." All patients were given a standard mixed diet for at least 5 days prior to testing the glucose tolerance.

Orthostatic blood pressure regulation was tested in the majority of cases.

As a test for adrenal insufficiency, the chloride concentration in urine, following a test diet poor in $\mathrm{Na}$, rich in $\mathrm{K}$, has been employed (Cutler, Power, and Wilder (6)). This test will be referred to as the Cutler test.

\section{OBSERVATIONS AND RESULTS}

Since in Addison's disease there is a high concentration of $\mathrm{Cl}$ in the urine under the conditions of the Cutler test (225 mgm. per cent and above), it was thought that less pronounced adrenal insufficiency, or "mild hypoadrenia," might be recognized through a $\mathrm{Cl}$ concentration at or above the upper limit of normal.

Our findings are tabulated in Table I. As will be discussed later in this paper, the Cutler test was performed repeatedly in some of the cases. Each case is listed only once in this table, under the highest excretion observed.

1 J. Ewing Mears Fellow in Physiology and Medicine.
Studies similar to those reported in this paper were performed in a number of cases which at first, on the basis of their personality and the nature of their complaints, impressed us as possibly belonging to this group. In the course of clinical studies, some organic disease was found or suspected and such cases were consequently not included in this report, despite the fact that the organic findings did not always seem responsible for the complaints or failed to explain them adequately.

The table shows that 23 out of 50 patients did not complain of asthenia. Such patients with vague complaints, in some instances with low blood pressure, in which careful clinical observation failed to reveal any physical disorder, seemed to us to be more adequate "controls" than normal healthy individuals.

It will be seen from Table I that out of 27 patients complaining of asthenia, 11 had a $\mathrm{Cl}$ concentration of more than $125 \mathrm{mgm}$. per cent, and 3 of these, a $\mathrm{Cl}$ concentration of more than $225 \mathrm{mgm}$. per cent. Of the 22 patients not definitely complaining of asthenia but resembling the asthenia cases in some respects, only 3 had a concentration of more than $125 \mathrm{mgm}$. per cent.

$\mathrm{Na}$ excretion was determined together with the $\mathrm{Cl}$ excretion in 7 cases. The three highest values observed are given in the table.

Since a $\mathrm{Cl}$ concentration of $225 \mathrm{mgm}$. per cent and above has been considered indicative of Addison's disease, the case histories of the 4 cases showing such high $\mathrm{Cl}$ excretions are given in brief abstract.

Case 15. A Polish woman, aged 58 years, was admitted with complaints of cramps in stomach, belching, loss of appetite, weakness. Her complaints had lasted many years and she had been treated with various drugs. Twelve years ago, cholecystectomy had been performed in the hope of relieving her. The operation failed to help. At present, the possibility of postoperative adhesions was considered, but physical and roentgenographic examinations were entirely normal. She was 
TABLE I

Cl excretion during 4-hour period of third day of Cutler test, in relation to clinical manifestations

\begin{tabular}{|c|c|c|c|c|c|c|}
\hline $\begin{array}{l}\text { Range of } \\
\text { of } \mathrm{Cl}^{-} \\
\text {excretion* }\end{array}$ & $\begin{array}{c}\text { Number } \\
\text { of } \\
\text { cases }\end{array}$ & & $\begin{array}{l}\text { Positive } \\
\text { psychiatric } \\
\text { findings }\end{array}$ & Hypotension & $\begin{array}{c}\text { Orthostatic } \\
\text { blood pressure } \\
\text { drop }\end{array}$ & $\begin{array}{c}\text { Flat glucose } \\
\text { tolerance } \\
\text { curve }\end{array}$ \\
\hline $\begin{array}{c}\text { mgm. per } 100 c c . \\
23 \text { to } 125\end{array}$ & 36 & $\begin{array}{c}\text { "Asthenia" } \\
16 \\
\text { No "Asthenia" } \\
20\end{array}$ & $\begin{array}{l}13 \\
12\end{array}$ & $\begin{array}{l}9 \\
3\end{array}$ & $\begin{array}{l}0 \\
1\end{array}$ & $\begin{array}{l}5 \\
6\end{array}$ \\
\hline 125 to 225 & 10 & $\begin{array}{c}\text { "Asthenia" } \\
\mathbf{8}_{* *}^{* *} \\
\text { No "Asthenia" } \\
2 * * *\end{array}$ & $\begin{array}{l}6 \\
2\end{array}$ & $\begin{array}{l}4 \\
2\end{array}$ & $\begin{array}{l}1 \\
0\end{array}$ & $\begin{array}{l}1 \\
1\end{array}$ \\
\hline Over 225 & 4 & $\begin{array}{c}\text { "Asthenia" } \\
3^{*}+{ }^{*} \\
\text { No "Asthenia" } \\
1\end{array}$ & $\begin{array}{l}2 \\
1\end{array}$ & $\begin{array}{l}2 \\
1\end{array}$ & $\begin{array}{l}0 \\
0\end{array}$ & $\begin{array}{l}3 \\
1\end{array}$ \\
\hline
\end{tabular}

5 feet tall and weighed 98 pounds. Psychiatric diagnosis by Dr. B. L. Keyes and Dr. R. A. Matthews, to whom we are indebted for the psychiatric examination of all cases of this study, was anxiety neurosis with conversion. A glucose tolerance test showed: fasting, $72 \mathrm{mgm}$. per cent; 1 hour after 100 grams of glucose (orally), $81 \mathrm{mgm}$. per cent; 2 hours, $114 \mathrm{mgm}$. per cent; 3 hours, $102 \mathrm{mgm}$. per cent; 4 hours, $77 \mathrm{mgm}$. per cent; 5 hours, $98 \mathrm{mgm}$. per cent; 6 hours, $80 \mathrm{mgm}$. per cent. Her blood pressure in the recumbent position was $94 / 62$, and in the erect position, 100/64. At times, her blood pressure while recumbent was as high as $150 / 80$. The Cutler test showed that during the 4-hour period of the third day, she excreted $250 \mathrm{cc}$. urine, with a $\mathrm{Cl}$ concentration of $228 \mathrm{mgm}$. per cent and a $\mathrm{Na}$ concentration of $114 \mathrm{mgm}$. per cent.

In spite of these findings, it was not believed that this patient had Addison's disease. She was dismissed with the diagnosis of psychoneurosis.

Six months later she was again studied. Her condition was unchanged. Her glucose tolerance curve was again "flat": fasting, $69 \mathrm{mgm}$. per cent; 1 hour after 100 grams of glucose (orally), $75 \mathrm{mgm}$. per cent; 2 hours, $93 \mathrm{mgm}$. per cent; 4 hours, $58 \mathrm{mgm}$. per cent; 5 hours, $68 \mathrm{mgm}$. per cent; 6 hours, $67 \mathrm{mgm}$. per cent. The Cutler test showed that during the 4-hour period of the third day, she excreted $820 \mathrm{cc}$. urine, with a $\mathrm{Cl}$ concentration of $77 \mathrm{mgm}$. per cent.

Fifteen months later another study was made. She had gained 30 pounds, but her condition was otherwise unchanged. A glucose tolerance test showed: fasting, 80 mgm. per cent; $1 / 2$ hour after 100 grams of glucose, 122 mgm. per cent; 1 hour, 117 mgm. per cent; 2 hours, $102 \mathrm{mgm}$. per cent. The Cutler test demonstrated that, during the 4-hour period of the third day, $740 \mathrm{cc}$. urine were excreted, with a $\mathrm{Cl}$ concentration of $14 \mathrm{mgm}$. per cent.
Case 19. An Italian woman, aged 38 years, was admitted with complaints of nervousness, weakness, and pains and aches in her arms and legs. The physical examination was entirely negative. She weighed 102 pounds; her blood pressure was $120 / 80$ in the recumbent position, $118 / 82$ in the erect position; B. M. R. was plus 8. The glucose tolerance test showed: fasting, 70 mgm. per cent; 1 hour after 100 grams of glucose (orally), 54 mgm. per cent; 2 hours, 92 mgm. per cent; 3 hours, $71 \mathrm{mgm}$. per cent; 4 hours, $66 \mathrm{mgm}$. per cent; 5 hours, $66 \mathrm{mgm}$. per cent ; 6 hours, $66 \mathrm{mgm}$. per cent. The Cutler test showed that during a 4-hour period of the third day, $140 \mathrm{cc}$. of urine were excreted, $\mathrm{Cl}$ concentration $311 \mathrm{mgm}$. per cent. This test was repeated several days later. The urine volume was $140 \mathrm{cc}$, and the $\mathrm{Cl}$ concentration, $411 \mathrm{mgm}$. per cent. Psychiatric diagnosis: psychoneurosis.

Patient was re-examined one year later. She had received no glandular substitution therapy. An appendectomy had been performed elsewhere since the above mentioned studies were made. She had tolerated the operation well. Her general condition was unchanged. She refused readmission for further study.

Case 21. A Jew, aged 40 years, was admitted with complaints of weakness and exhaustion, coming in attacks during the past 7 months. Physical examination was entirely negative. Psychiatric examination did not reveal any psychoneurosis. His weight was 134 pounds; his height, $671 / 2$ inches. His blood pressure was $96 / 54$ in the recumbent position and $102 / 60$ in the erect position. A glucose tolerance test showed: fasting, $93 \mathrm{mgm}$. per cent; 1 hour after 100 grams of glucose (orally), 108 mgm. per cent; 2 hours, $77 \mathrm{mgm}$. per cent; 3 hours, 85 mgm. per cent; 4 hours, $71 \mathrm{mgm}$. per cent; 5 hours, 67 mgm. per cent; 6 hours, 71 mgm. per cent; B. M. R. was plus 1. The Cutler test showed that during the 4-hour 
period of the third day, the urine excretion and $\mathrm{Cl}$ concentrations were $110 \mathrm{cc}$., $\mathrm{Cl} 228 \mathrm{mgm}$. per cent; $840 \mathrm{cc}$, $\mathrm{Cl} 43 \mathrm{mgm}$. per cent; and $420 \mathrm{cc}$., $\mathrm{Cl} 61 \mathrm{mgm}$. per cent.

The patient was questioned one year later. He had not consulted his physician because he had felt well.

Case 38. A Jewess, aged 33, was admitted with complaints of dizziness and palpitations. Physical examination, roentgenogram, and electrocardiogram were entirely normal. Her height was 64 inches; her weight, 138 pounds. Blood pressure was $110 / 75$, but at times up to $130 / 80$. Results of a glucose tolerance test were: fasting, $68 \mathrm{mgm}$. per cent; 1 hour after 100 grams of glucose (orally), $106 \mathrm{mgm}$. per cent; 2 hours, $100 \mathrm{mgm}$ per cent; 3 hours, $70 \mathrm{mgm}$. per cent; 4 hours, $76 \mathrm{mgm}$. per cent; 5 hours, $81 \mathrm{mgm}$. per cent; 6 hours, $79 \mathrm{mgm}$. per cent. B. M. R. was plus 7. The Cutler test showed that during the 4 hours of the third day, $100 \mathrm{cc}$. of urine were excreted with a $\mathrm{Cl}$ concentration of $225 \mathrm{mgm}$. per cent. Psychiatric diagnosis: psychoneurosis.

Patient was next seen $1 \frac{1}{2}$ years later. Her condition was unchanged. Because of amenorrhea, a gynecologist had given her estrogenic hormones and thyroid, both of which were tolerated well, but failed to influence her condition. She was readmitted to the hospital in order to repeat the Cutler test. She then excreted during the 4 hour period of the third day, $760 \mathrm{cc}$. urine with 2 $\mathrm{Cl}$ concentration of $76 \mathrm{mgm}$. per cent.

It is clear from the observation of these 4 patients, over a period of from 1 to 2 years, that none of them was a case of Addison's disease. In addition, it may be pointed out that one of these patients (Case 19) was operated upon successfully without any of the precautions and procedures necessary in Addison's disease. Another (Case 38) showed no ill effects from thyroid medication received elsewhere, whereas patients with Addison's disease react unfavorably to thyroid therapy. The variation of $\mathrm{Cl}$ excretion on repeated testing will be discussed later.
The following observation led us one step further. In one case, some doubt was raised as to whether the regime during the test had been properly and accurately maintained. The $\mathrm{Cl}$ excretion had been excessively high (341 mgm. per cent $\mathrm{Cl}$ ). The test was repeated one week later and the $\mathrm{Cl}$ excretion was low $(7 \mathrm{mgm}$. per cent Cl). No information is available as to the variation of the $\mathrm{Cl}$ excretion in the same individual at different times. Willson and associates (7) found the $\mathrm{Cl}$ excretion of a patient suffering from Addison's disease, on whom the test was performed at different times, to be remarkably constant. When we began to test our patients more than once, at short intervals, a considerable variation of $\mathrm{Cl}$ excretion in the Cutler test was observed. Since the majority of our patients were young women, we thought of an influence of the menstrual cycle. Thorn and his associates (8) have shown the sex steroids to induce salt and water retention when injected into dogs. In human females, this salt and water retaining effect on the individual's own estrogenic hormone may be potent enough to produce premenstrual weight increase and edema (9). It was consequently thought possible that the result of the Cutler test might vary considerably in different phases of the menstrual cycle.

Five healthy female volunteers were therefore subjected to the procedure of the Cutler test every week for one month. The regime of these 5 girls differed from that of our patients inasmuch as they were not hospitalized or at bed rest during the test periods. They all continued their activities as technical assistants in the laboratories. However, their meals were prepared by the diet kitchen in the hospital. All drinking water was

TABLE II

Cutler tests performed at weekly intervals on normal healthy young girls

\begin{tabular}{|c|c|c|c|c|c|c|c|c|c|}
\hline & \multirow{2}{*}{ Weight } & \multicolumn{2}{|c|}{ Test 1} & \multicolumn{2}{|c|}{ Test 2} & \multicolumn{2}{|c|}{ Test 3} & \multicolumn{2}{|c|}{ Test 4} \\
\hline & & $\mathrm{Cl}$ & $\begin{array}{c}\text { Urine } \\
\text { volume }\end{array}$ & $\mathrm{Cl}$ & $\begin{array}{c}\text { Urine } \\
\text { volume }\end{array}$ & $\mathrm{Cl}$ & $\begin{array}{c}\text { Urine } \\
\text { volume }\end{array}$ & $\mathrm{Cl}$ & $\begin{array}{c}\text { Urine } \\
\text { volume }\end{array}$ \\
\hline $\begin{array}{l}\text { M. S. } \\
\text { K. H. } \\
\text { K. E. } \\
\text { J. L. } \\
\text { L. B. (1) }\end{array}$ & $\begin{array}{l}\mathrm{kgm.} \\
57.3 \\
51.8 \\
63.0 \\
51.8 \\
61.6\end{array}$ & $\begin{array}{c}\text { mgm. per } 100 \text { cc. } \\
* 23 \\
20 \\
32 \\
* 66 \\
* 28\end{array}$ & $\begin{array}{l}c c . \\
720 \\
760 \\
870 \\
340 \\
930\end{array}$ & $\begin{array}{c}\text { mgm. per } 100 \text { cc. } \\
38 \\
* 28 \\
36 \\
31 \\
45\end{array}$ & $\begin{array}{r}c c . \\
1240 \\
460 \\
1000 \\
930 \\
620\end{array}$ & $\begin{array}{c}\text { mgm. per } 100 \text { cc. } \\
31 \\
20 \\
* 31 \\
88 \\
40\end{array}$ & $\begin{array}{r}c c . \\
910 \\
630 \\
960 \\
300 \\
1180\end{array}$ & $\begin{array}{c}\text { mgm. per } 100 \text { cc. } \\
35 \\
26 \\
35 \\
30 \\
*\end{array}$ & $\begin{array}{r}c c . \\
900 \\
350 \\
1000 \\
460\end{array}$ \\
\hline
\end{tabular}

$\mathrm{Cl}$ : Concentration and urine volume during 4-hour period on third day of Cutler Test.

* Menstruation occurring between respective tests.

(1): L. B. menstruated irregularly. Menstruations three weeks apart during observation period. 
TABLE III

Cl excretion and urine volume during 4-hour period of third day of Cutler Test. Results of repeated tests

\begin{tabular}{|c|c|c|c|c|}
\hline $\begin{array}{c}\text { Case } \\
\text { number }\end{array}$ & Test 1 & Test 2 & Test 3 & Test 4 \\
\hline 15 & $\begin{array}{c}228 \text { mgm. per cent }(250 \text { cc.) } \\
\text { (January } 23,1941)\end{array}$ & $\begin{array}{l}77 \text { mgm. per cent }(820 \mathrm{cc} .) \\
\text { (June } 26,1941)\end{array}$ & 14 mgm. per cent (740 cc.) & \\
\hline 19 & $\begin{array}{l}311 \text { mgm. per cent }(140 \text { cc.) } \\
\text { (May 12, 1941) }\end{array}$ & $\begin{array}{l}411 \underset{\text { (May } 20,1941)}{\text { mgm. per cent }}(140 \mathrm{cc} .) \\
\text { (May }\end{array}$ & & \\
\hline 21 & $\begin{array}{c}228 \underset{\text { mgm. per cent }}{\text { (June } 28,110 \mathrm{cc} .)}) \\
\text { (J) })\end{array}$ & $\begin{array}{l}43 \text { mgm. per cent }(840 \text { cc.) } \\
\text { (July } 7,1941)\end{array}$ & $\begin{array}{l}61 \text { mgm. per cent }(420 \text { cc.) } \\
\text { (July } 12,1941)\end{array}$ & \\
\hline 24 & $\begin{array}{c}104 \text { mgm. per cent }(370 \mathrm{cc} .) \\
\text { (August 28, 1941) }\end{array}$ & $\begin{array}{c}25 \text { mgm. per cent }(600 \mathrm{cc} .) \\
\text { (September } 15,1941)\end{array}$ & $\begin{array}{l}74 \text { mgm. per cent }(780 \mathrm{cc} .) \\
\text { (October 20, 1941) }\end{array}$ & \\
\hline 25 & $\begin{array}{c}197 \text { mgm. per cent }(570 \text { cc.) } \\
\text { (August } 9,1941)\end{array}$ & $\begin{array}{l}45 \text { mgm. per cent (740 cc.) } \\
\text { (August 27, 1941) }\end{array}$ & 33 mgm. per cent $(450 \mathrm{cc})$. & $\begin{array}{c}106 \text { mgm. per cent (485 cc.) } \\
\text { (September } 8,1942)\end{array}$ \\
\hline 27 & $\begin{array}{l}202 \text { mgm. per cent ( } 80 \text { cc.) } \\
\text { (July 20, 1942) }\end{array}$ & $\begin{array}{l}86 \text { mgm. per cent }(330 \mathrm{cc} .) \\
\text { (July } 30,1942)\end{array}$ & & \\
\hline 30 & $\begin{array}{l}86 \text { mgm. per cent }(500 \mathrm{cc} \text {.) } \\
\text { (August } 30,1942)\end{array}$ & $\begin{array}{c}157 \text { mgm. per cent }(390 \mathrm{cc} .) \\
\text { (September } 25,1942)\end{array}$ & & \\
\hline 37 & $\begin{array}{c}86 \text { mgm. per cent }(300 \text { cc.) } \\
\text { (September } 16,1941)\end{array}$ & 93 mgm. per cent $(385 \mathrm{cc})$. & & \\
\hline 38 & 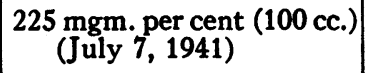 & $\begin{array}{l}76 \text { mgm. per cent }(760 \mathrm{cc} .) \\
\text { (October } 10,1941)\end{array}$ & & \\
\hline 41 & $\begin{array}{l}\text { *341 mgm. per cent }(60 \mathrm{cc} .) \\
\text { (July } 2,1941)\end{array}$ & $\begin{array}{l}7 \text { mgm. per cent }(260 \text { cc.) } \\
\text { (July } 7,1941)\end{array}$ & $\begin{array}{l}118 \text { mgm. per cent }(230 \text { cc.) } \\
\text { (July } 14,1941)\end{array}$ & $\begin{array}{l}63 \text { mgm. per cent (610 cc.) } \\
\text { (July } 21,1941)\end{array}$ \\
\hline 45 & $\begin{array}{c}133 \text { mgm. per cent }(45 \mathrm{cc} .) \\
\text { (February } 5,1942)\end{array}$ & $\begin{array}{l}68 \text { mgm. per cent }(500 \text { cc. }) \\
\text { (February } 19,1942)\end{array}$ & & \\
\hline 50 & $\begin{array}{c}172 \text { mgm. per cent }(60 \mathrm{cc} \text { ) } \\
\text { (December } 2,1941)\end{array}$ & $\begin{array}{c}112 \text { mgm. per cent }(220 \text { cc.) } \\
\text { (March } 30,1942)\end{array}$ & & \\
\hline
\end{tabular}

* This first test was possibly due to an error in procedure (see page 31). This case is therefore listed in Table I under the range 23 to $125 \mathrm{mgm}$. per cent.

distilled. On the days between the tests, a mixed diet was taken. Table II gives the results. It can be seen that there is little variation in the excretion of these normal individuals. None of them suffered from premenstrual edema or premenstrual tension. It is possible that in women suffering from premenstrual tension and/or edema, the disturbed salt-water metabolism might influence the results of the test. It is, however, obvious that in the normal subject, the rhythmic changes in sex steroid production are not capable of overcoming the rigorous conditions of the test.

In the further course of our studies, we found considerable variation of $\mathrm{Cl}$ concentration in the tests performed on post-menopausal women and in male individuals. This further emphasizes the fact that this variation is independent of the ovarian cycle.
In Table III, the variations observed on repeated tests are listed. None of the changes could be attributed to any form of treatment. As a matter of fact, in those instances in which the test was repeated at short intervals during one hospital stay of the patient, no treatment was given during the interval. The changes of $\mathrm{Cl}$ excretion observed did not coincide with any change of the clinical picture or of the subjective complaints.

The considerable variability of intermediate metabolism is not limited to $\mathrm{Cl}$ retention. A case in point is Case 25.

S. L., a Jew, aged 26 , complained of extreme weakness and difficulty of breathing and swallowing. He was obsessed by the idea that something was wrong in his chest. Repeated examinations, including roentgenography and laryngoscopy, failed to detect any organic disease. 
He was greatly emaciated, weighing 86 pounds (38.7 $\mathrm{kgm}$.), height $63 \frac{1}{2}$ inches $(154 \mathrm{~cm}$.). His blood pressure varied from $80 / 60$ to $120 / 80$. The Cutler test showed a urine volume, in 4 hours of the third day, of $570 \mathrm{cc}$. with a $\mathrm{Cl}$ concentration of $198 \mathrm{mgm}$. per cent; several days later it was $335 \mathrm{cc}$. with a $\mathrm{Cl}$ concentration of $46 \mathrm{mgm}$. per cent. The fasting blood sugars were as follows: November 6, $38 \mathrm{mgm}$. per cent; November 7, $82 \mathrm{mgm}$. per cent; November 11, 56 mgm. per cent. His B. M. R. was minus 16; several weeks later, while his condition was unchanged, the B. M. R. was plus 14 . The psychiatric diagnosis was psychoneurosis, possibly incipient schizophrenia. Anorexia nervosa was also considered.

Further management of the patient proved impossible. He went from one hospital to another. In the course of one year, following the above mentioned studies, he was admitted to different hospitals four times, including one admission to a psychiatric department. He returned to Jefferson Hospital after one year. His weight had further decreased to 74 pounds. His glucose tolerance was: fasting, $71 \mathrm{mgm}$. per cent; $1 / 2$ hour after 100 grams of glucose (orally), $115 \mathrm{mgm}$. per cent; 1 hour, $115 \mathrm{mgm}$. per cent; 2 hours, 112 mgm. per cent. The Cutler test showed a urine excretion, during 4 hours of the third day, of $485 \mathrm{cc}$. with a $\mathrm{Cl}$ concentration of $106 \mathrm{mgm}$. per cent.

This case shows, in addition to variation of $\mathrm{Cl}$ concentration in the Cutler test, a very considerable variation of fasting blood sugars.

Glucose tolerance. Seventeen of all our cases showed a flat glucose tolerance curve. Nine of these were asthenia cases. Dorst (10) has previously drawn attention to the flat glucose tolerance curve of patients with neurocirculatory asthenia. It should be emphasized that, both in our cases and in Dorst's series, glucose tolerance was tested by oral administration of glucose. The "flat" curves may be caused by a disturbance of resorption since normal curves were obtained in a few cases following intravenous administration of glucose. In no case did we encounter the exaggerated posthyperglycemic hypoglycemia, characteristic of Addison's disease.

Blood pressure. Blood pressure was low in 21 cases, 15 of these being in the asthenia group. Systolic pressures below $120 \mathrm{~mm}$. $\mathrm{Hg}$ were listed as low. Six cases showed clearly hypotensive values (systolic pressure below 100, diastolic pressure below 60). Two patients presented orthostatic hypotension, one of them was in the asthenia group.

\section{DISCUSSION}

Cutler and his associates (6) stated that normal persons, as well as patients suffering from dis- eases other than Addison's disease, do not excrete chloride in excess of $125 \mathrm{mgm}$. per cent in a 4hour urine sample collected on the third day of the test. - The values in patients with Addison's disease were $225 \mathrm{mgm}$. per cent or above. Dryerre (11) believes that the determination of $\mathrm{Na}$ concentration, under the conditions of the Cutler test diet, gives more satisfactory results than the determination of $\mathrm{Cl}$. Cutler and his associates, having determined both $\mathrm{Cl}$ and $\mathrm{Na}$ concentration, found changes of both ions to be parallel and therefore advocated the much simpler determination of $\mathrm{Cl}$. Willson, Robinson, Power, and Wilder (7) have recently reported on further experience with this test. They confirm generally the findings published previously by Cutler et al. They find the upper limit of normality at $156 \mathrm{mgm}$. per cent of $\mathrm{Cl}$, and at $85 \mathrm{mgm}$. per cent of $\mathrm{Na}$, in the urine of the 4-hour period of the third test day.

Stephens (12) reported 2 cases of hypopituitarism in which the Cutler test revealed $\mathrm{Cl}$ excretion of a degree indicative of adrenal cortical insufficiency, which is to be expected in such cases.

Thorn, Howard, and Dayman (13) studied 60 patients with pulmonary tuberculosis. In all, the $\mathrm{Cl}$ excretion was well within normal range. The 2 with the highest $\mathrm{Cl}$ excretion were suspected of having Addison's disease.

In the first report by Cutler, Power, and Wilder (6), the figures for cases without Addison's disease were analyzed. In this series, neither the mean nor the range of $\mathrm{Cl}$ concentration of cases of "asthenia" differed from those in other cases without Addison's disease or from those in healthy normal men and women. However, only 6 cases of "asthenia" were examined.

It has been found in this study that a number of asthenic patients excrete chlorides at or above the upper limit of "normality" under the conditions of the Cutler test. Four of these patients excreted chlorides in amounts usually considered diagnostic for Addison's disease. The question may be raised whether this is due to functional impairment of the adrenal cortex. $\mathrm{Na}$ and $\mathrm{Cl}$ metabolism is influenced by a number of conditions. Chronic infections, especially tuberculosis, neoplasm, and cardiac failure could be ruled out in our cases $(13,14)$. Inanition is a factor which deserves brief discussion since a number of our patients, though not all, had lost some weight. 
Rubin and Krick (15) have found that in partially starved rats, the balance of $\mathrm{Cl}$ and $\mathrm{Na}$ and of a number of other electrolytes is negative. Mulinos and Pomerantz (16) have shown that starvation in animals produces atrophy of the adrenals and other endocrine glands. It would seem possible that the patients studied in our investigation would lose appetite on the basis of their neurosis. The consequent partial starvation would cause a depression of various glands, including the adrenal cortex. This decreased function would in turn produce various metabolic disturbances and would furthermore decrease appetite, food resorption, and food utilization, thereby increasing starvation. This is the mechanism presumably operating in cases of anorexia nervosa which, in all metabolic functions, simulates pituitary cachexia. High $\mathrm{Cl}$ excretion under the conditions of the Cutler test has been found in pituitary cachexia (12). In a case of anorexia nervosa, not included in this report, we found a strongly positive Cutler test. However, we do not feel that the results in our patients can be ascribed to inanition. One reason is that some of the patients showing high $\mathrm{Cl}$ excretion did not present any appreciable weight loss and their general appearance was not that of starvation. Secondly, the considerable variations of the $\mathrm{Cl}$ excretion, occurring within short periods in some of the individuals, would seem to preclude starvation as a cause of the high $\mathrm{Cl}$ excretion.

We can then state that some patients suffering from exhaustion and asthenia, most of them psychoneurotics, respond to the $\mathrm{Na}$ privation and $\mathrm{K}$ ingestion (test of Cutler and associates) with higher chloride excretion than do normal individuals. In some cases, the magnitude of the $\mathrm{Cl}$ excretion is such as is generally considered indicative of Addison's disease. Since these patients did not suffer from Addison's disease, a positive Cutler test may be misleading and cannot be considered proof of Addison's disease. The transient nature of this disturbance in our asthenia cases not suffering from Addison's disease should be stressed.

Low blood pressure was noted in 21 cases, 6 of which were clearly hypotensive. Two patients presented postural hypotension. Postural hypotension may be due to a great variety of factors, (17 to 20). In untreated cases of Addison's dis- ease, the postural hypotension is known to be severe $(21,22,19)$.

We believe that our results might be interpreted as indicative of adrenal cortical involvement in some cases of asthenia. This should not, however, imply that we consider these asthenias and neuroses to be caused by adrenal cortical insufficiency. The considerable variability of the $\mathrm{Cl}$ balance as shown in several of our cases militates against the assumption of any organic defect of the adrenal cortex. The fact that variations of the chloride retaining power are not accompanied by corresponding changes in the general condition of the patients makes it very unlikely that even functional transitory insufficiency of the adrenal cortex is the cause or a main contributing factor of the sufferings.

Hypothetically, the explanation of the metabolic findings reported in this paper may rather be sought on the basis of an unstable personality. This instability manifests itself in the psychological sphere as psychoneurosis. The manifestations in the somatic sphere may be very varied.

It seems plausible to assume that the secretion of hormones would participate in this general instability. Variations in blood sugar content may be partly mediated through variations in the output of epinephrine, which in turn is regulated by sympathetic nerve impulses. The adrenal cortex would seem to share the instability of these patients. Whereas the innervation of the adrenal medulla is well recognized, the question of nerve supply of the adrenal cortex is far from settled (23). The variability of output of adrenal cortical hormone might well be part of the personality picture without necessarily being under direct nervous control.

McFarland and Goldstein, in their review of biochemistry of the psychoneuroses (24), come to the conclusion that "in the analysis of the biological reactions of psychoneurotics it appears that their failure to achieve compensation quickly and smoothly may be one of the most important aspects of the illness."

It will readily be seen that the cases discussed in this paper might be subsumed under various headings. Some of them would be described as "types of chétifs" in the French literature. Some would come under the heading of "organ neurosen" of German authors. Reimann's cases of 
sympathicotonia and vagotonia seem to resemble a number of our cases (25). Alvarez (26) would regard most of them as "constitutional inadequates." Their endocrine instability is evidently part of their personality, not necessarily its cause. These patients are not suffering from "mild hypoadrenia," and are not mild cases of Addison's disease. These terms would imply that the adrenal cortical insufficiency is the cause of the disease. As mentioned in the introduction, the existence of such a condition might be expected to occur, but we have yet to recognize it.

\section{SUMMARY}

1. The chloride excretion test of Cutler, Wilder, and Power has been studied in 50 patients, 27 of whom complained of asthenia, in whom clinical observation failed to reveal any organic disease. Thirty-eight of the patients were found to be psychoneurotic. $\mathrm{Cl}$ concentration was $125 \mathrm{mgm}$. per cent (upper limit of "normal" according to Cutler et al.) or above, in 13 cases. The Cl concentration was $225 \mathrm{mgm}$. per cent or above in 4 patients not suffering from Addison's disease and not suffering from any organic disorder.

2. The chloride excretion test was performed two or more times in 12 cases. A considerable variability in chloride retaining power was found in 11 , even when the test was repeated at short intervals.

3. In 5 normal control cases, chloride excretion showed little variation and no influence of the menstrual cycle.

4. It is concluded that some patients suffering from asthenia and exhaustion may temporarily show signs of adrenal cortical insufficiency. Observation of these patients showed that they were not suffering from mild Addison's disease or "mild hypoadrenia:" If their inability to conserve $\mathrm{Cl}$ is due to lowering of the function of the adrenal cortex, this hypofunction is temporary. It is thought possible that such fluctuations of adrenal cortical function may be part of a general instability of such personalities.

\section{BIBLIOGRAPHY}

1. Gordon, E. S., Sevringhaus, E. L., and Stark, M. E., The use of adrenal cortex preparations in the treatment of asthenia. Endocrinology, 1938, 22, 45.
2. Hartman, F. A., Beck, G. M., and Thorn, G. W., Improvement in nervous and mental states under cortin therapy. J. Nerv. and Ment. Dis., 1933, 77, 1.

3. Hartman, F. A., Greene, C. W., Bowen, B. D., and Thorn, G. W., Further experience with cortin therapy. J. A. M. A., 1932, 99, 1478.

4. Huddleson, J. H., and McFarland, R. A., The response of chronically fatigued neurotic patients to adrenal cortex therapy. Endocrinology, 1939, 25, 853.

5. Loehmer, C. A., Further observations on the use of adrenal cortex extract in the psychotic and nonpsychotic patient. Endocrinology, 1940, 27, 378.

6. Cutler, H. H., Power, M. H., and Wilder, R. M., Concentrations of chloride, soduim and potassium in urine and blood. Their diagnostic significance in adrenal insufficiency. J. A. M. A., 1938, 111, 117.

7. Willson, D. M., Robinson, F. J., Power, M. H., and Wilder, R. M., Diagnosis of Addison's disease. Arch. Int. Med., 1942, 69, 460.

8. Thorn, G. W., and Harrop, G. A., The "sodium retaining effect" of the sex hormones. Science, 1937, 86, 40.

9. Thorn, G. W., and Emerson, K., Jr., The role of gonadal and adrenal cortical hormones in the production of edema. Ann. Int. Med., 1940, 14, 757.

10. Dorst, S., Chronic hypoglycemia. Am. J. M. Sc., 1938, 196, 688.

11. Dryerre, H. W., Addison's disease. Edinburgh $M$. J., 1939, 46, 267.

12. Stephens, D. J., Pituitary and adrenocortical insufficiency. J. Clin. Endocrinol., 1941, 1, 109.

13. Thorn, G. W., Howard, R. P., and Dayman, H., Electrolyte changes in pulmonary tuberculosis with special reference to adrenal cortical function. Bull. Johns Hopkins Hosp., 1940, 67, 345.

14. Winkler, A. W., and Crankshaw, O. F., Chloride depletion in conditions other than Addison's disease. J. Clin. Invest., 1938, 17, 1.

15. Rubin, M. I., and Krick, E. T., The salt and water metabolism of adrenal insufficiency and partial starvation in rats. J. Clin. Invest., 1936, 15, 685.

16. Mulinos, M. G., and Pomerantz, L., Hormonal influences on the weight of the adrenal in inanition. Am. J. Physiol., 1941, 132, 368.

17. Jeffers, W. A., Montgomery, H., and Burton, A. C., Types of orthostatic hypotension and their treatment. Am. J. M. Sc., 1941, 202, 1.

18. McLean, A. R., and Allen, E. V., Orthostatic hypotension and orthostatic tachycardia. J. A. M. A., 1940, 115, 2162.

19. Spingarn, C. L., and Hitzig, W. M., Orthostatic circulatory insufficiency. Its occurrence in tabes dorsalis and Addison's disease. Arch. Int. Med., 1942, 69, 23.

20. Stead, E. A., Jr., and Ebert, R. V., Postural hypotension. Arch. Int. Med., 1941, 67, 546. 
21. Ratner, J., Die hypophysär-suprarenale Insuffizienz und das Schellong-Strisowersche Phänomen. Ztschr. f. klin. Med., 1935, 127, 713.

22. Schur, M., Zur Frage der endokrin-nervösen Blutdruckregulierung im Stehen und nach Arbeit. Wien. Arch. f. inn. Med., 1936, 29, 271.

23. Teitelbaum, H. A., The innervation of the adrenal gland. Quart. Rev. Biol., 1942, 17, 135.
24. McFarland, R. A., and Goldstein, H., Biochemistry of the psychoneuroses. Am. J. Psychiat., 1937, 93, 1073.

25. Reimann, H. A., Hypothermia. J. A. M. A., 1940, 115, 1606.

26. Alvarez, W. C., Constitutional inadequacy. J. A. M. A., 1942, 119, 780. 